\title{
A NEW SPHAERALCEA.
}

Sphaeralcea martii, n. sp.-Perennial, low and rather spreading, I 5 to $30^{\mathrm{cm}}$ high: leaves and stems whitish-green with an excessively dense white stellate pubescence: leaves subhastate, with broad short basal lobes, crinkled, edges coarsely irregularly serrate, about $27^{\mathrm{mm}}$ long and ${ }_{1} 5^{\mathrm{mm}}$ wide; petioles about $10^{\mathrm{mm}}$ long: flowers large, $23^{\mathrm{mm}}$ in diameter, in clusters of six or seven at the ends of the branches; pedicels 5 to $7^{\mathrm{mm}}$ long: calyx I I $^{\mathrm{mm}}$ to tip of lobes, $4^{\mathrm{mm}}$ to base of lobes : petals fully $5^{\mathrm{mm}}$ long and broad, rather pale but vivid scarlet (dull pink in dry material): anthers orange; pollen bright orange: styles crimson: fruit maliform, densely white-hairy; carpels with very small beaks; ovules two in a cell.

Picacho mountain, Mesilla valley, New Mexico, in volcanic soil, March 25, I900 (Cockerell); hills north of Picacho mountain, April 7, I 900 , in fruit (E. O. Wooton). A specimen is in Herb. U. S. National Museum.

Differs from S. subhastata in its pointed leaves, clustered flowers, deeply cleft calyx with long acuminate lobes, and especially in its early flowering, wherein it resembles the annual species. The only flowering date I find reported for $S$. subhastata is in August.-T. D. A. Cockerell, East Las Vegas, N. M. 